\title{
Agro-morphological characterization of local garlic (Allium sativum L.) germplasm accessions collected from different regions of Jammu and Kashmir
}

Sheikh M. Sultan*

ICAR-National Bureau of Plant Genetic Resources, Regional Station Srinagar, Srinagar191132(UT), India

Susheel Kumar Raina

ICAR-National Bureau of Plant Genetic Resources, Regional Station Srinagar, Srinagar191132(UT), India

*Corresponding author. E-mail: sheikhmsultan@gmail.com

\begin{abstract}
Garlic (Allium sativum L.) is increasingly becoming an essential component in human diet due to tremendous health-promoting benefits; its traditional local types are preferred for their taste. Garlic clones have specific adaptations to different agro-climatic regions; some have adapted to specific environments through artificial and natural selection. The study was undertaken to assess the variation in some agro-morphological characters of 17 local garlic germplasm accessions collected from different regions of Jammu and Kashmir including far-flung areas of Karthaie Padder Kishtwar and Balot Bhaderwah Doda. Most of these local garlic germplasm accessions are characterized by more pungent smell and distinctive taste often with pigmented coat layers. Some of these accessions have been cryo-preserved in National Gene Bank at ICAR-NBPGR New Delhi. The results have demonstrated the existence of a good amount of agro-morphological diversity in these local garlic germplasm accessions. Different ecotypes exhibit considerable variation among themselves in agronomic characteristics. Therefore, there is a need for concerted efforts for exploration, collection and maintenance of locally available garlic germplasm possessing quality traits including disease and pest resistance besides good storability characteristics for future garlic crop improvement programmes in the region.
\end{abstract}

Keywords: Agro-morphological traits, Allium sativum, Cloves, Local germplasm, Variability

\section{INTRODUCTION}

Garlic (Allium sativum L.) belonging to family Liliaceae is one of the oldest and important horticultural crops cultivated by man. It is native to Central Asia having around five thousand years of history. Its primary centre of origin is Central Asia (Kazakhstan), and the secondary centre is the Mediterranean and Caucasus zones (Etoh and Simon, 2002). Garlic (Allium sativum L.) has acquired a reputation in different traditions as a prophylactic as well as a therapeutic medicinal plant having played important dietary and medicinal roles throughout history (Jiku et al., 2020). Garlic is one of the most popular spices in the world. Due to its taste and health-promoting values, it has become an essential component in the human diet all over the world (Matłok et al., 2014). The nutritional and health values of garlic result from its high content of biologically active substances such as organic sulfides, saponins, phenolic compounds and polysaccharides, the con- centration of which depends on ensuring suitable conditions of growth and development for the plants during the period of vegetation (Matysiak et al. 2015).

China is the chief producer of garlic in the world, accounting for $70 \%$ of total production followed by India. In India, garlic is an important bulb crop after onion. The main garlic producing states in India are Rajasthan, Madhya Pradesh, Uttar Pradesh and Gujarat. However, long day garlic requiring long photoperiod of more than $13 \mathrm{hrs}$. with warm temperature of $20-25{ }^{\circ} \mathrm{C}$ for bulbing is cultivated only in temperate regions, especially in Jammu and Kashmir, Himachal Pradesh, and Uttarakhand (Geetika et al., 2017). Early sowing, longer photoperiod and higher temperatures have been found to have a profound effect on the formation and quality of bulbs in garlic (Atif et al., 2020). In the union territory of Jammu and Kashmir, garlic has a long history of cultivation, grown on a small scale almost everywhere chiefly for domestic use. Countless ecotypes have resulted 
through artificial and natural selection over a period of time. Most of these ecotypes are characterized by small bulbs having cloves with pigmented coat layer besides possessing a very sharp smell, distinctive taste and disease and pest resistance, besides having good storability characteristics. However, during the last few decades, these local garlic genetic resources have increasingly been lost.

Garlic is a diploid species $(2 n=2 x=16)$ of obligated apomixis and therefore is essentially a vegetatively propagated crop. Based on morphological and physiological variability, garlic has been subdivided into two horticultural groups or subspecies, namely sativum known as common or Mediterranean garlic and ophioscorodon known as Asiatic garlic (Hanelt, 1990). The ophioscorodon subspecies generally develop floral stalks while sativum subspecies does not develop floral stalks (Etoh and Simon, 2002). Despite its infertility, the crop displays a wide range of variation under various ecological conditions, and some germplasms have adapted to specific environments through artificial and natural selection (Lu et al., 2001). The agro-morphological traits such as bulb weight, coat layer, leaf length, growth habit and stress resistance have shown wide variations (Fan et al., 1997; Lu et al., 2001; Volk and Stern, 2009; Kumar et al., 2015; Ayed et al., 2019). Assessment of such germplasm resources is thus necessary for their effective use (Kamenetsky, 2007). Identification and characterization of ecotypes with valuable traits is fundamental for enhancing the genetic base of garlic germplasm in a particular region. The present study was therefore undertaken to assess the variation in morphological features of local garlic genotypes collected by our Regional Station during last few years from different areas falling in both Kashmir and Jammu divisions of Jammu and Kashmir. Some of these genotypes have been Cryo-preserved in National Gene Bank at ICAR-NBPGR New Delhi.

\section{MATERIALS AND METHODS}

The present study was carried out on 17 accessions of garlic (Allium sativum L.) germplasm collected earlier from different parts of Jammu and Kashmir. Bulbs and cloves of some genotypes are shown in Fig. 1. The experiment was laid out during 2018/19 in a randomized complete block design with three replications at the Experimental Field of ICAR-NBPGR Regional Station Srinagar, Jammu and Kashmir (33 $59^{\prime} \mathrm{N}$ latitude, $74^{\circ} 47^{\prime} \mathrm{E}$ longitude, $1639 \mathrm{~m}$ above sea level, average monthly rainfall $52 \mathrm{~mm}$, soil (clay: silt: sand in the ratio of 33: 60: 7 and $\mathrm{pH}$ 6.23). Healthy looking and uniform sized cloves of particular genotypes were planted during last week of September 2018 in $3 \mathrm{~m}$ rows at a depth of $5 \mathrm{~cm}$ each with a row spacing of $30 \mathrm{~cm}$ and the plant spacing of $10 \mathrm{~cm}$.
Standard cultural practices were followed for raising the crop (Anonymous, 2009). Weeds were removed by hand whenever necessary. The morphological characters of plant height, leaf length and leaf width were measured at the end of the growth stage. Ten plants were randomly selected and marked from each genotype in each replica ignoring those on the peripheries for recording data on plant height $(\mathrm{cms})$, leaf length $\left(\mathrm{cms}, 3^{\text {rd }}\right.$ leaf from the base) and leaf width ( $\mathrm{cms}, 3^{\text {rd }}$ leaf from the base). The crop was harvested when leaves on plants turned brown during the first week of June 2019. The bulbs were stored traditionally at ambient temperature in a well-ventilated room for a period of two months before bulb weight $(\mathrm{g})$ and number of cloves/bulb were measured.

The data obtained was subjected to statistical analysis and coefficient of variation (CV) was calculated to compare the genetic variation of quantitative traits among accessions. Analysis of variance (ANOVA) was performed and the significance of difference was compared by LSD analysis at the significance level of $\alpha=0.05$. Besides, Pearson correlation coefficients for the relationships between all the quality traits were calculated using Statistical Package for the Social Sciences (SPSS) software, version 16.

\section{RESULTS AND DISCUSSION}

The results obtained during the course of the present investigation have been summarized and presented in Table 1. The results demonstrate existence of a good amount of agro-morphological diversity in 17 local garlic genotypes which have been originally collected from various parts of Jammu and Kashmir including far-flung areas in Kishtwar and Doda districts. The differences observed in many cases are statistically significant. Plant height has been found to range from 36.4 $79.8 \mathrm{cms}$ while leaf length ranged from 29.5 $47.3 \mathrm{cms}$, leaf width from $1.4-2.9 \mathrm{cms}$, No. of cloves/blub from 5.6 - 10.1 and blub weight from $16.477-58.545 \mathrm{~g}$. Lowest plant height of $36.4 \mathrm{cms}$ with corresponding lowest blub weight has been recorded in primitive garlic cultivar collected from Karthaie Padder Kishtwar. This genotype is characterized by small cloves with a more pungent

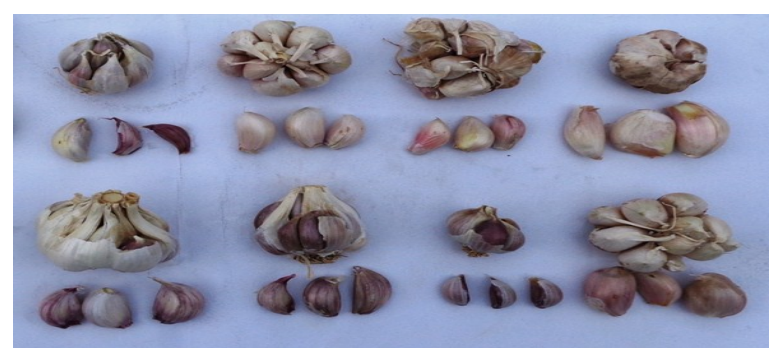

Fig 1. Bulbs and cloves of some local garlic primitive cultivars used in the present study. 
Sultan, S.M. and Raina, S. K. / J. Appl. \& Nat. Sci. 12(2): 124 - 127 (2020)

Table 1. Mean performance of some agro morphological traits in 17 local genotypes of Allium sativum.

\begin{tabular}{|c|c|c|c|c|c|c|c|c|c|}
\hline Accession No. & $\begin{array}{l}\text { Plant } \\
\text { (cm) }\end{array}$ & height & $\begin{array}{l}\text { Leaf } \\
(\mathrm{cm})\end{array}$ & length & $\begin{array}{l}\text { Leaf } \\
(\mathrm{cm})\end{array}$ & width & $\begin{array}{l}\begin{array}{l}\text { Number } \\
\text { cloves/bulb }\end{array} \\
\end{array}$ & $\begin{array}{l}\text { Bulb } \\
\text { (g) }\end{array}$ & weight \\
\hline IC-0622295 & 69.8 & & 37.1 & & 2.5 & & 10.1 & 36.938 & \\
\hline IC-0622296 & 61.0 & & 31.8 & & 2.0 & & 9.3 & 37.462 & \\
\hline IC-0622297 & 59.8 & & 38.3 & & 2.6 & & 7.0 & 25.206 & \\
\hline IC-0622298 & 72.9 & & 31.9 & & 1.6 & & 9.4 & 30.859 & \\
\hline IC-0622299 & 65.3 & & 34.5 & & 1.7 & & 9.3 & 33.135 & \\
\hline IC-0622300 & 69.4 & & 42.9 & & 2.4 & & 9.7 & 37.980 & \\
\hline IC-0622301 & 71.2 & & 44.3 & & 1.7 & & 9.7 & 58.545 & \\
\hline IC-0622302 & 69.0 & & 47.3 & & 2.5 & & 9.2 & 34.442 & \\
\hline IC-0622303 & 75.2 & & 44.0 & & 2.7 & & 8.7 & 40.050 & \\
\hline IC-0622304 & 76.3 & & 40.6 & & 2.9 & & 7.7 & 34.250 & \\
\hline IC-0622305 & 50.1 & & 43.0 & & 1.4 & & 7.9 & 28.162 & \\
\hline IC-0622306 & 75.7 & & 45.8 & & 1.7 & & 8.2 & 29.587 & \\
\hline IC-0622307 & 79.8 & & 39.9 & & 2.4 & & 8.6 & 31.269 & \\
\hline IC-0622308 & 36.4 & & 36.0 & & 1.4 & & 5.6 & 16.477 & \\
\hline IC-0622309 & 79.0 & & 29.5 & & 1.6 & & 8.2 & 22.403 & \\
\hline IC-0622310 & 71.8 & & 32.8 & & 1.7 & & 7.7 & 22.708 & \\
\hline IC-0622311 & 65.0 & & 34.1 & & 1.7 & & 8.4 & 35.035 & \\
\hline Mean & 67.5 & & 38.5 & & 2.0 & & 8.5 & 32.621 & \\
\hline $\mathrm{CV}$ & 16.3 & & 14.3 & & 24.3 & & 13.2 & 28.3 & \\
\hline LSD at $P=0.05$ & 20.4 & & 9.7 & & 0.8 & & 2.2 & 18.419 & \\
\hline
\end{tabular}

Table 2. Pearson correlation coefficients among some agro-morphological characters in 17 local genotypes of Allium sativum.

\begin{tabular}{llllll}
\hline \multicolumn{1}{c}{ Trait } & Plant height & Leaf length & Leaf width & No. of cloves/blub & Bulb weight \\
\hline Plant height & 1.000 & & & & \\
Leaf length & 0.081 & 1.000 & & & \\
Leaf width & 0.401 & 0.388 & 1.000 & 1.000 & \\
No. of cloves/blub & $0.541^{*}$ & 0.116 & 0.200 & $0.722^{* *}$ & 1.000 \\
Bulb weight & 0.355 & 0.419 & 0.263 & \\
\hline
\end{tabular}

${ }^{*}$ Correlation significant at 0.01 level ${ }^{* *}$ and at 0.05 level

smell. Maximum blub weight $(58.545 \mathrm{~g})$, leaf length $(47.3 \mathrm{cms})$ and leaf width $(2.9 \mathrm{cms})$ have been recorded in garlic genotypes collected from Central Kashmir district of Budgam. In a study on agro-morphological characterization of 41 genotypes of Alliums including 27 genotypes of Allium sativum collected from different zones of Jammu division, bulb weight has been found to range from $8.56-43.40 \mathrm{~g}$, leaf length from $15.4-37.0$ cms and plant height from $22.00-52.10 \mathrm{cms}$ (Kumar et al., 2015). Their results have also shown that average bulb weight showed positive and significant correlation with a number of leaves/plant, leaf length, the average weight of cloves, equatorial diameter, while it was negative and significantly correlated with total soluble solids. Computation of simple correlation in our present study has revealed that plant height is positively correlated with leaf width, bulb weight and No. of cloves/bulb, being significant in the latter case (Table 2). Leaf length shows a positive correlation with leaf width and bulb weight, while bulb weight shows a much stronger and highly significant positive correlation with No. of cloves/bulb. In some studies in other parts of the world bulb mass has been found to vary from 39.65 - $64.62 \mathrm{~g}$ (Majkowska-Gadomska et al. 2019). Earlier studies have recorded a considerably lower garlic bulb mass, varying from $7.57-14.47 \mathrm{~g}$ (Albuquerque et al. 2017) and 4.87 - $17.51 \mathrm{~g}$ (Yeshiwas et al. 2018). In a study on 36 Tunisian garlic landraces, Ayed et al. (2019) have reported that leaf length ranged from $34.61-47.53 \mathrm{cms}$, leaf width from $1.07-2.19 \mathrm{cms}$, bulb weight from $13.43-32.29 \mathrm{~g}$ and No. of cloves/bulb from as low as 4.67 to as high as 27.81. The results of all these studies including those in our present study reveal the existence of high agro-morphological diversity among different garlic ecotypes which also posses specific adaptations to different agro-climatic regions implying that morphological characteristics can vary under different agro-climatic conditions. In an analysis of 65 garlic clones using Random Amplified Polymorphic DNA (RAPD) study, a genetic similarity rate of $94 \%$ has been recorded and $70 \%$ of these were clustered in one major group signifying low genetic diversity (Paredes et al., 2008). On the other hand, abundant genetic variation has been reported among Chinese garlic germplasms using different molecular markers besides such analysis showed that there is a certain relationship between latitude and ecotype of garlic (Li et al., 2007, Chen et al., 2013). Our study similarly indicated the presence of a wide spectrum of variability in agro- morphological traits among the local garlic germplasm accessions collected from different latitudes and 
altitudes underlying the need for extensive exploration and collection of locally available garlic germplasm for crop improvement programmes in the region.

\section{Conclusion}

The study demonstrated the existence of a good amount of agro-morphological diversity in 17 local germplasm accessions of $A$. sativum. Different ecotypes exhibited considerable variations among themselves in agronomic characteristics with plant height ranging from $36.4-79.8 \mathrm{cms}$, No. of cloves/ blub from 5.6-10.1 and blub weight from 16.477$58.545 \mathrm{~g}$. Therefore, there is a good scope for further exploration, collection and maintenance of locally available garlic germplasms possessing quality traits, including disease and pest resistance besides good storability characteristics.

\section{ACKNOWLEDGEMENTS}

The authors are thankful to the Director, ICARNBPGR and the Head, Division of Exploration and Germplasm Collection, ICAR-NBPGR, New Delhi for their guidance and help in exploration and collection of garlic accessions used in the present investigation.

\section{REFERENCES}

1. Albuquerque, J. R. A., Monteiro, H. N. B., Bezerra, A. A. C., Filho, C. H. A., Lopes, A. C. A. and Gomes, R. L. F. (2017). Agromorphological performance of garlic landraces in Piauí, Brazil. Cienc. Rural, 47(6): 2 6, https://doi.org/10.1590/0103-8478cr20160017

2. Anonymous (2009) Package of practices for vegetable crops. Directorate of Extension Education, Dr YS Parmar University of Horticulture and Forestry, Nauni, Solan. India, 202p.

3. Atif, M. J., Amin, B, Ghani, M. I., Ali, M. and Cheng, Z. (2020). Variation in Morphological and Quality Parameters in Garlic (Allium sativum L.) Bulb Influenced by Different Photoperiod, Temperature, Sowing and Harvesting Time. Plants, 9: 155, doi:10.3390/ plants9020155

4. Ayed, C., Mezghani, N., Rhimi, A. and Mohandes Dridi, B. A. L. (2019). Morphological evaluation of Tunisian garlic (Allium sativum L.) landraces for growth and yield traits. Journal of Horticulture and Postharvest Research, 2(1): 43 - 52.

5. Chen, S., Zhou, J., Chen, Q., Chang, Y., Du, J. and Huanwen, M. (2013). Analysis of the genetic diversity of garlic (Allium sativum L.) germplasm by SRAP. Biochemical Systematics and Ecology, 50: 139-146.

6. Etoh, T. and Simon. P. W. (2002). Diversity, fertility and seed production of garlic. In Rabinovitch, H. D. and Currah, L. (eds.) Allium crop science: Recent advances. CABI Publishing, Wallingford, UK, pp. 101 $-117$.

7. Fan, Z. C., Lu, G. Y. and Du, H .F. (1997). Study on ecotype classification of garlic varieties. Acta Phytoecol. Sinica, 21 (2), 169 - 174.
8. Geetika, M., Mahajan, V., Dhatt, A. S., Singh, D. B., Sharma, A., Mir, J. I., Sajad, H. W., Yousuf, S., Shabir, A. and Malik, A. A. (2017). Present status and future prospects of garlic (Allium sativum L.) improvement in India with special reference to long day type. Journal of Pharmacognosy and Phytochemistry, 6(5): 929 - 933.

9. Hanelt, P. (1990). Taxonomy, evolution, and history. In Rabinovitch, H.D. and Brewster, J. L. (eds.) Onions and allied crops. Vol. 1. Botany, physiology and genetics. CRC, Boca Raton, Florida, USA, pp. 1 - 26.

10.Jiku, M. A. S., Alimuzzaman, M., Singha, A., Rahaman, M. N., Ganapati, R. K., Alam, M. A. and Sinha, S. R. (2020). Response and productivity of Garlic (Allium sativum L.) by different levels of potassium fertilizer in farm soils. Bulletin of the National Research Centre, 44: 9, https://doi.org/10.1186/s42269020-0267-7

11.Kamenetsky, R. (2007) Garlic: Botany and Horticulture. Horticultural Reviews, 33: $123-172$.

12.Kumar, S., Samnotra, R. K., Kumar, M. and Khar, S. (2015). Character association and path analysis in garlic (Allium spp.) germplasm under sub tropical environment of Jammu. The Bioscan, 10(4): 1997 . 2003.

13.Li, H. Z., Yin, Y. P., Zhang, C. Q., Zhang, M. and Li, J. M. (2007) Evaluation of application of SRAP on analysis of genetic diversity in germplasms of Allium fistulosum L. Acta Hort. Sinica, 34 (4): 929-934

14.Lu, G. Y., Fan, Z. C. and Du, H. F. (2001). Relationship Between Ecotypes of Garlic (Allium sativum L.) Germplasms and Introduction, vol. 294. Northwest Sci-Tech University of Agriculture and Forestry, pp. $55-59$.

15.Majkowska-Gadomska, J., Mikulewicz, E., Jadwisieńczak, K., Francke, A. and Młyńska, K. (2019).The influence of amino acid biostimulators on the size and quality of garlic (Allium sativum L.). Acta Agroph., 26 (4): 31 - 38, doi: 10.31545/aagr/116644

16.Matłok, N., Gorzelany, J., Bilek, M., Pieniążek, R., Kuźniar, P. and Kaniuczak, J. (2014). Estimation of the content of fructose, glucose and saccharose in selected onion cultivars cultivated at three breeding and seed-production farms (in Polish). Zesz. Probl. Post. Nauk Rol., 576: 79 - 87.

17.Matysiak, M., Gaweł-Bęben, K., Rybczyńska, K., Gmiński, J. and Surma, S. (2015). Comparison of selected biological properties of garlic (Allium sativum L.) cultivated in Poland and in China (in Polish). ŻNTJ, 2(99): 160 - 169.

18.Paredes, C. M., Becerra, V. and González, A. M. I. (2008). Low genetic diversity among garlic (Allium sativum L.) accessions detected using Random Amplified Polymorphic DNA (RAPD). Chilean Journal of Agricultural Research, 68(1): 3 - 12.

19.Volk, G. M. and Stern, D. (2009). Phenotypic characteristics of ten garlic germplasms grown at different North American locations. Hortscience, 44: 1238 1247.

20.Yeshiwas, Y., Belete, N., Tegibew, W., Yohaness, G., Melke A. and Kassahun Y. (2018). Collection and characterization of garlic (Allium sativa L.) germplasm form growth and bulb yield at Debre Markos, Ethiopia. Journal of Horticulture and Forestry, 10(3):17-26 